Article

\title{
Resolving Stack Effect Problems in a High-Rise Office Building by Mechanical Pressurization
}

\author{
Jung-yeon $\mathrm{Yu}^{1}{ }^{1}$, Kyoo-dong Song ${ }^{2, *}$ and Dong-woo Cho ${ }^{3}$ \\ 1 Department of Architectural Engineering, Graduate School, Hanyang University, Seoul 04763, Korea; \\ starry101@hanyang.ac.kr \\ 2 Department of Architecture and Architectural Engineering, Hanyang University, ERICA Campus, Ansan, \\ Gyeonggi-Do 15588, Korea \\ 3 Korea Institute of Civil Engineering \& Building Technology, 283 Goyangdae-Ro, Ilsanseo-gu, Goyang-Si, \\ Gyeonggi-Do 10223, Korea; dwcho@kict.re.kr \\ * Correspondence: kdsong@hanyang.ac.kr; Tel.: +82-10-3630-5135; Fax: +82-31-408-6335
}

Received: 5 September 2017; Accepted: 22 September 2017; Published: 26 September 2017

\begin{abstract}
In high-rise buildings, the stack effect causes various problems, especially problems related to excessive pressure differences across main entrance doors and elevator doors, particularly in heating seasons. To reduce the stack effect, this study aims to find effective operation schemes for the HVAC systems in a 60-story commercial building, located in Seoul, Korea. Field measurements were conducted to identify the problems related to the stack effect in the building. Computer simulations were conducted to examine the effectiveness of various HVAC operation schemes in reducing the stack effect. Then, an optimum and effective operation scheme was adopted from the computer simulation results and applied in the field. The adopted scheme was used to pressurize the upper zone of the building. Through field application and an adjustment process, a proper amount of air volume was found to effectively pressurize the upper zone of this building, solving the problems related to the stack effect. The required air volume for pressurization was maintained in the building by reducing the volume of the exhaust air (EA) while maintaining a constant volume of outdoor air (OA).
\end{abstract}

Keywords: stack effect; high-rise buildings; mechanical pressurization; HVAC operation schemes

\section{Introduction}

Stack effect takes place in buildings due to buoyancy of heated air moving upward. The stack effect in buildings plays a positive role in intermediate and cooling seasons by increasing the natural ventilation through the buildings [1,2]. Buildings having an atrium space, large scale factory buildings having a high ceiling combined with operable openings, and solar chimneys are some good examples.

However, the stack effect in high-rise buildings in heating seasons causes various problems [3] such as malfunctioning elevator doors, annoying whistling noises in elevator halls, increased infiltration through the main entrance, increased heating loads, and the rapid spread of fire and smoke if a fire breaks out $[4,5]$. Therefore, many studies have been conducted to develop architectural and mechanical methods to reduce the stack effect in high-rise buildings [3-24].

In Korea, many high-rise buildings have been built for residential and commercial uses since the early 1980s. Up until the early 2000s, many of these high-rise buildings were designed without considering proper architectural and mechanical methods to reduce the stack effect. As a result, many of these buildings have been remodeled or are being investigated in an attempt to solve problems related to the stack effect, and the stack effect has emerged as an important issue in designing high-rise buildings. 
According to previous studies [3,4,6-10], one effective architectural measure to reduce the stack effect is to increase the number of walls between the elevator shaft and the building envelope. However, many commercial buildings require more openness on typical floors for office spaces consisting of multiple work stations divided by low-height interior partitions. For these types of buildings, mechanical methods may be considered to reduce infiltration at floors below the neutral pressure level, such as pressurization of the building interior by HVAC systems [3-5,11-16].

The goal of this study was to find effective operation schemes for the HVAC systems in a 60-story commercial building located in Seoul, Korea to reduce the stack effect during the heating season. The building had suffered a severe stack effect problem related to large pressure differences across the elevator doors on the first floor. HVAC operation schemes were developed to reduce this problem by pressurizing floors in a vertical range; various floor ranges were considered and compared, as well as various quantities of air for pressurization. This study was conducted by taking the following steps.

(1) Field measurements were conducted to identify the magnitude of the pressure difference causing the malfunction of elevator doors in this particular building.

(2) Computer simulations were conducted to identify the proper vertical grouping of floors and the required volume of air for pressurization by the HVAC systems considering the winter outdoor design dry bulb temperature condition in the Seoul area.

(3) The results from the computer simulations were then applied to the actual building by pressurizing the upper part of the building, including floors 40-60. During this phase, the actual volume of air for pressurization was adjusted according to measured pressure differences across the elevator doors.

\section{Literature Review}

\subsection{Stack Effect in High-Rise Buildings}

When the stack effect occurs in a high-rise open-plan office building, the greatest pressure differences across the elevator doors are usually measured at the first floor and the top floor (Figure 1a). However, when the upper floors are pressurized by the HVAC systems, the air flow rate from the elevator shaft to the office spaces on the upper floors is reduced, and the air flow rate from the lobby space on the first floor to the elevator shaft is also reduced (Figure 1b). This method can greatly alleviate problems such as malfunctioning elevator doors and noise by reducing the pressure differences across the elevator shaft. Pressurizing every floor uniformly has little effect on the pressure differences across the floors and vertical shafts. If stack pressure across the entrance door is a concern, the pressurization of the first floor is often adopted [17]. In addition, when the inside of an elevator or stairwell shaft is pressurized, the pressure difference across the elevator doors on the first floor decreases while one on each floor of the neutral pressure level or above increases [18,19]. 


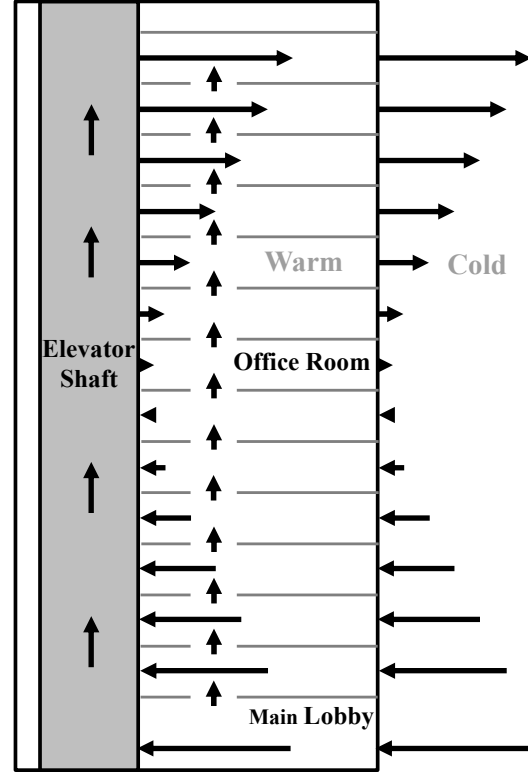

(a)

\section{Pressurization using HVAC system}

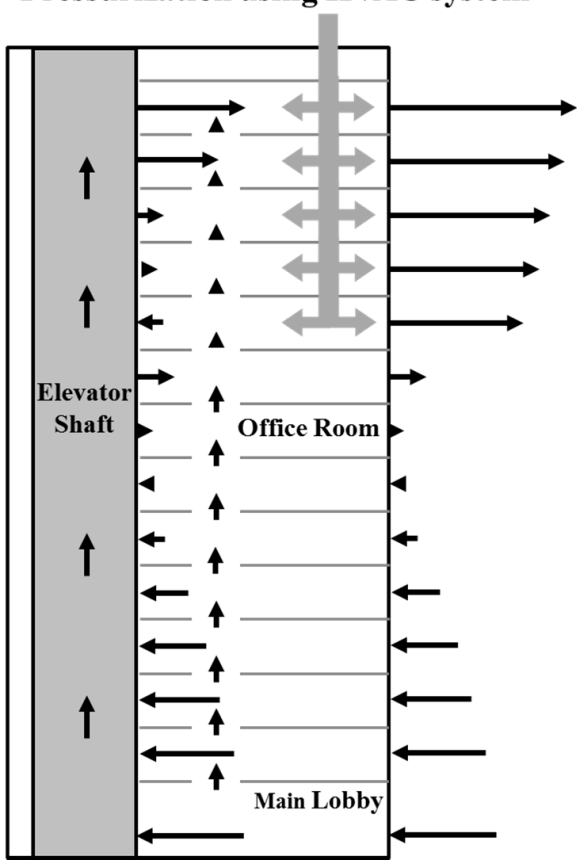

(b)

Figure 1. Typical air pressure distributions in high-rise buildings when the stack effect exists with HVAC pressurization on floors above neutral pressure level: (a) without pressurization; and (b) with pressurization on upper floors.

\subsection{Previous Studies}

Tamura [4] used field measurements and computer simulations to identify various pressure profiles under which the stack effect occurs according to the outdoor temperature, partitioning schemes, and operation conditions of the ventilation systems. Tamura developed a stack effect evaluation index called the thermal draft coefficient (TDC). The TDC indicates the level of air-tightness of the building envelope relative to the interior divisions. In that study, various architectural and mechanical measures were suggested to reduce the stack effect. While Tamura and Wilson originally applied the TDC concept to a whole building, Hayakaya et al. [6] applied the TDC to individual floors. Jo et al. [7] evaluated the characteristics of pressure distributions in high-rise residential buildings according to interior partitioning and elevator zoning schemes, and suggested a separation method by installing so-called "air lock doors" between the elevator doors and entrances to the residential units to reduce the pressure differences across those doors. Lstiburek [8] suggested the inclusion of air barriers to control infiltration and exfiltration, thereby maintaining the air-tightness of the interior spaces and the building as a whole. Based on the information and the design guidelines suggested by these studies to reduce the stack effect, most high-rise buildings recently built in Korea have been designed to include various architectural measures such as air-tightened building envelopes, revolving doors for the main entrance, air-lock doors for elevator halls, dedicated elevators for underground parking lots, and vertical zoning of elevator shafts.

These architectural measures have practically solved stack effect problems in high-rise residential buildings, in which numerous walls separate the housing units. However, because commercial buildings have many open-plan office spaces, the stack effect in these buildings has not been effectively reduced by architectural measures alone. Therefore, other measures to reduce the stack effect in high-rise commercial buildings have been developed and applied to several buildings. These measures include natural or mechanical cooling of elevator shafts and mechanical pressurization of elevator shafts and office spaces. Yu et al. [9] suggested that elevator shafts should be located in the perimeter 
zone to lower the air temperature within elevator shafts. In the study, stack effects were measured and compared between an elevator shaft located in the core zone and another one located in the perimeter zone with a glass wall exposed to the outdoors. The study found that the perimeter shaft had a much weaker stack effect owing to the lower air temperature within the shaft, resulting in a pressure difference across the elevator door in the perimeter shaft that is about half that of the core shaft. Lee et al. [20] conducted computer simulations and measurements of a building with multiple elevator shafts, located in Seoul, to investigate the effectiveness of mechanically cooling the elevator shafts with cold OA to reduce the pressure difference across elevator doors. In the computer simulations, the pressure difference was reduced by about $27 \%$ by cooling the elevator shafts from $22{ }^{\circ} \mathrm{C}$ to $12{ }^{\circ} \mathrm{C}$; field measurements showed a reduction of about $25 \%$ in air velocity through the elevator door on the first floor and by about $10 \%$ on the upper floors when the elevator shafts were cooled. However, this method requires extra building space for fan systems and ductwork, which should be prepared from the design stages, and also incurs extra costs for the mechanical systems. Therefore, this method may not be a practical solution for existing high-rise buildings if there is not enough space to accommodate the added mechanical systems and ductwork.

Some notable studies [3-5,11-16] mostly related to mechanical measures to reduce stack effect were conducted with various operation schemes using the HVAC systems to pressurize building spaces. Tamura and Wilson [11] used the ventilation system to reduce the air pressure in the upper zone and increase the pressure in the lower zone to reduce infiltration through the building skins. As a result, the operation could reduce infiltrated air volume by reducing the pressure differences across the building skins, but the pressure differences across the vertical shafts, including elevator doors and stairwell doors, increased.

On the other hand, Tamblyn [12] suggested increasing air pressure in the upper zone and decreasing pressure in the lower zone in order to reduce the pressure difference across the elevator shaft. Tamblyn emphasized the importance of airtightness of the building envelope to suppress infiltration, which might increase due to the lowered interior air pressure at the lower zone.

In the research project conducted by ASHRAE [13] for an existing high-rise building, the upper zone and mid zone were pressurized and the lower zone excluding the first floor for the lobby was depressurized. The results showed that the pressure differences across the elevator doors for the upper zone, mid zone, and the lobby floor were reduced. However, it was found that the pressure differences across the elevator doors for the lower zone exceeded $25 \mathrm{~Pa}$, which was known as the maximum pressure difference that does not cause the malfunction of the elevator doors. The research suggested that the mechanical balancing of air pressures for a limited number of floors at the top and bottom would be effective for buildings with loose airtight skins and buildings of more than $180 \mathrm{~m}$ in height.

From these previous studies, it was revealed that the depressurization of the lower zone caused high pressure differences across the elevator doors and building envelope for the lower zone. Therefore, pressurization of the upper zone only was adopted and tested in this study. Then, this study focused on finding the optimum vertical floor ranges and volumes of air for pressurization.

\section{Methods}

\subsection{Identifying Stack Effect Problems by Field Measurements}

A series of field measurements were conducted in a high-rise office building located in Seoul, Korea to identify problems related to the stack effect. As shown in Figure 2, the building has a total height of $245 \mathrm{~m}$, including the lobby height of $9 \mathrm{~m}$ and a typical floor height of $4 \mathrm{~m}$. The area of the lobby on the first floor is $2250 \mathrm{~m}^{2}$, and the areas of most floors vary from 1800 to $2250 \mathrm{~m}^{2}$, varying due to the curved shape of the building. The total volume of the building is about $500,000 \mathrm{~m}^{3}$. The passenger elevator shafts are designed for three separate vertical zones: the low-rise zone elevators serve Floors 1-20, mid-rise zone elevators depart from the first floor and stop at Floors 20-37, and high-rise zone elevators depart from the first floor and stop at the 37th floor and Floors 40-60. The 38th, 39th, 61st 
and 62nd floors are used as mechanical rooms, so the passenger elevators do not stop at these floors. In addition, two emergency staircases serve all 60 floors.

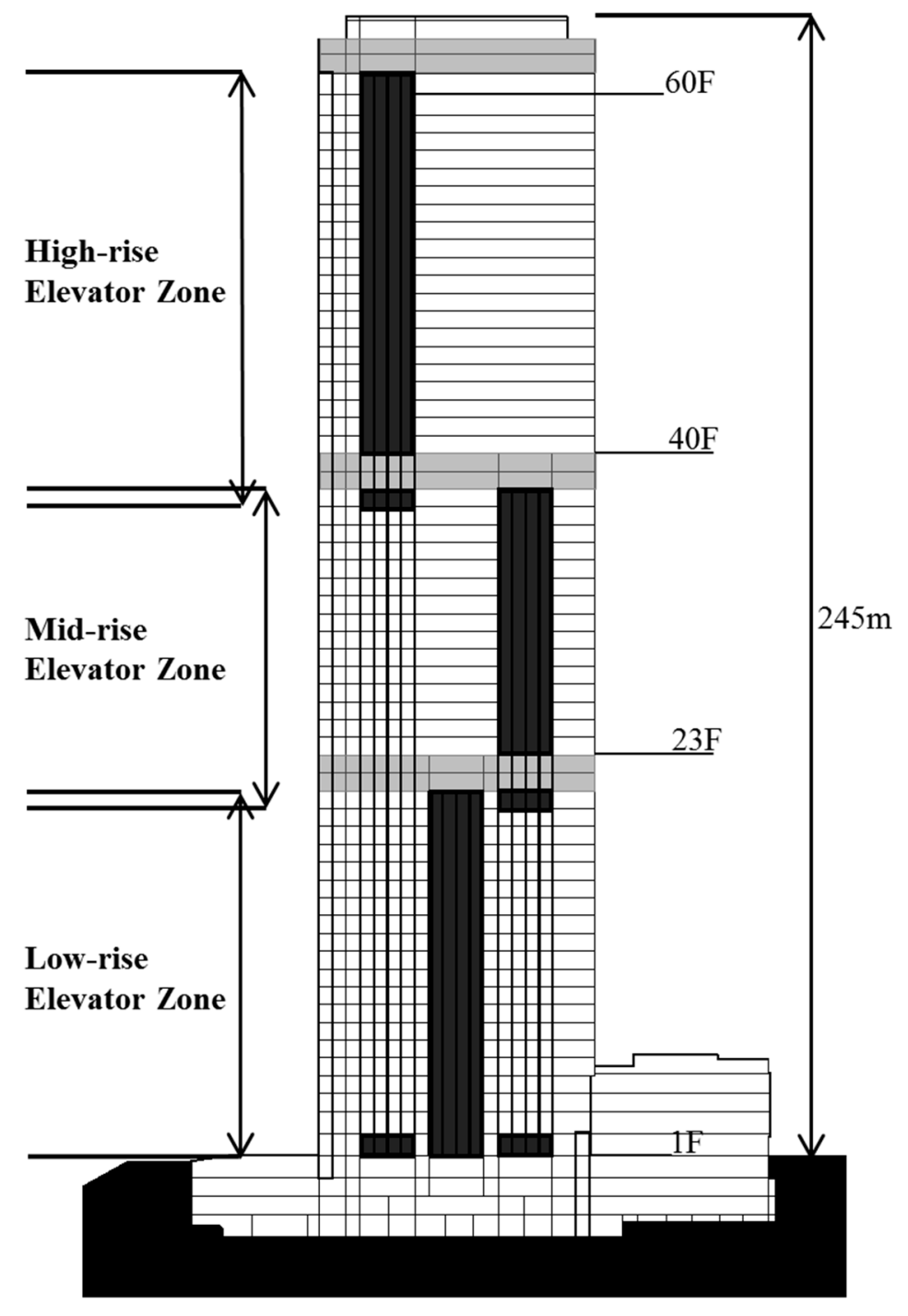

Figure 2. Section and elevator shaft zones of the test building.

Measurements of pressure differences $(\Delta \mathrm{Ps})$ across the elevator doors were conducted on selected floors between the first and 60th floors: Floors 1, 4, 8, 12, 16, 20, 25, 29, 33, 37, 41, 45, 48, 52 and 56. During the measurements, the outdoor and indoor air temperatures were, respectively, $-5.2{ }^{\circ} \mathrm{C}$ and $22{ }^{\circ} \mathrm{C}$, and the outdoor wind velocity was less than $1 \mathrm{~m} / \mathrm{s}$ at a height of $16 \mathrm{~m}$ from the ground level, which means that external wind pressure on the building was negligible. Figure 3 shows floor plans of the first floor and a typical floor (50th floor) between the 40th and 60th floors of the test building, including the measurement points.

Figure 4 shows the measured $\Delta \mathrm{Ps}$ across the elevator doors at different floors and shafts. The greatest $\Delta \mathrm{P}$ was $121 \mathrm{~Pa}$ across one of the first-floor doors of the high-rise elevator shaft. When the $\Delta \mathrm{P}$ was recorded at $121 \mathrm{~Pa}$, the elevator doors for the high-rise elevator shaft on the first floor were not closed. These malfunctions completely ceased when the $\Delta \mathrm{P}$ was reduced to about $100 \mathrm{~Pa}$. This value was much greater than the maximum value of $25 \mathrm{~Pa}$ recommended by ASHRAE [13] because the elevator doors installed on the first floor of this building were manufactured to properly operate at large $\Delta \mathrm{P}$ across the doors that exceeded ASHARE standards. The $\Delta \mathrm{P}$ for the low-rise and mid-rise 
elevator doors on the first floor were measured as $-25 \mathrm{~Pa}$ and $52 \mathrm{~Pa}$, respectively. Therefore, in this study, the evaluation criterion for pressure difference was set to $100 \mathrm{~Pa}$.

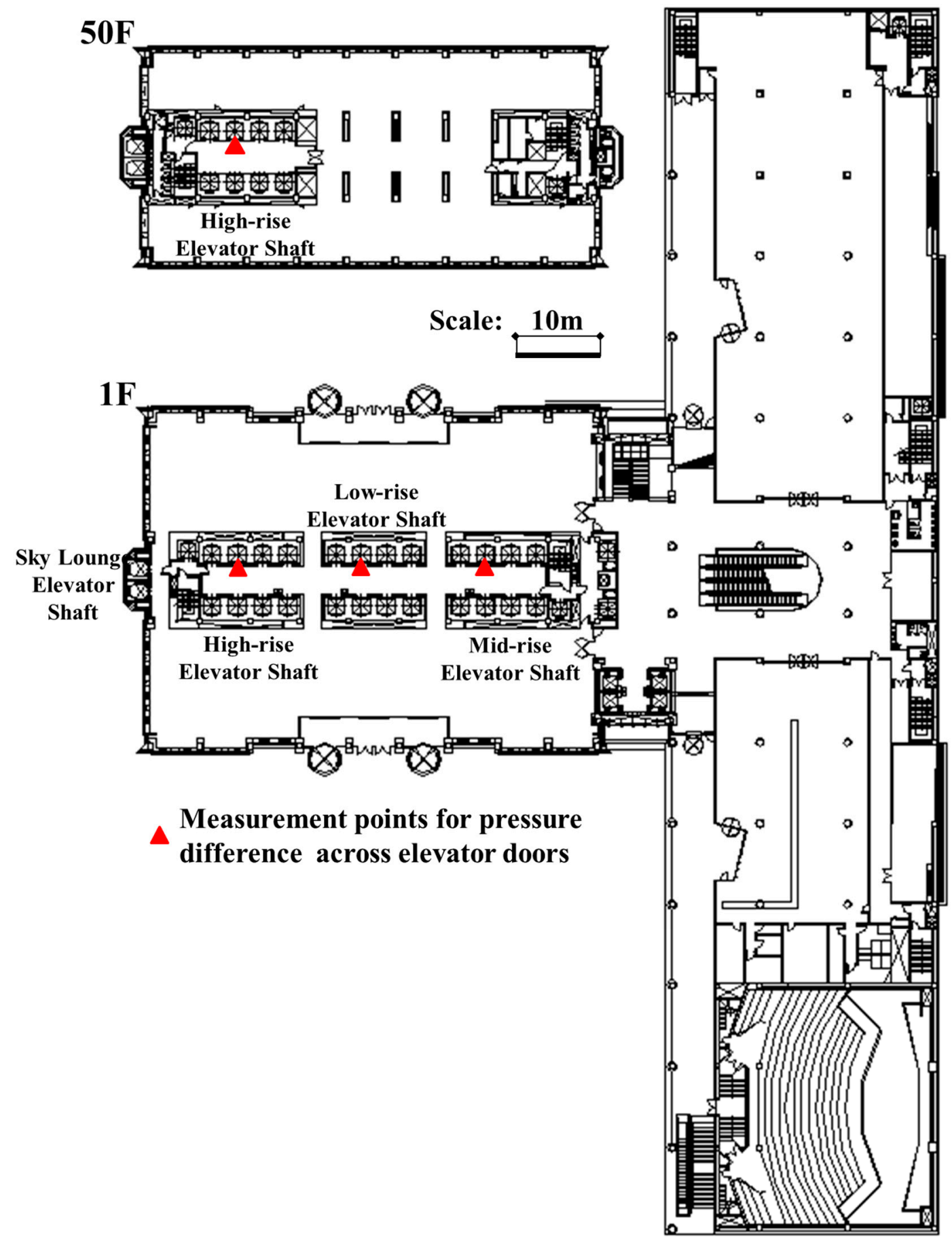

Figure 3. Floor plans and measurement points on the 1st floor and a typical floor (50th floor) serviced by a high-rise elevator shaft. 


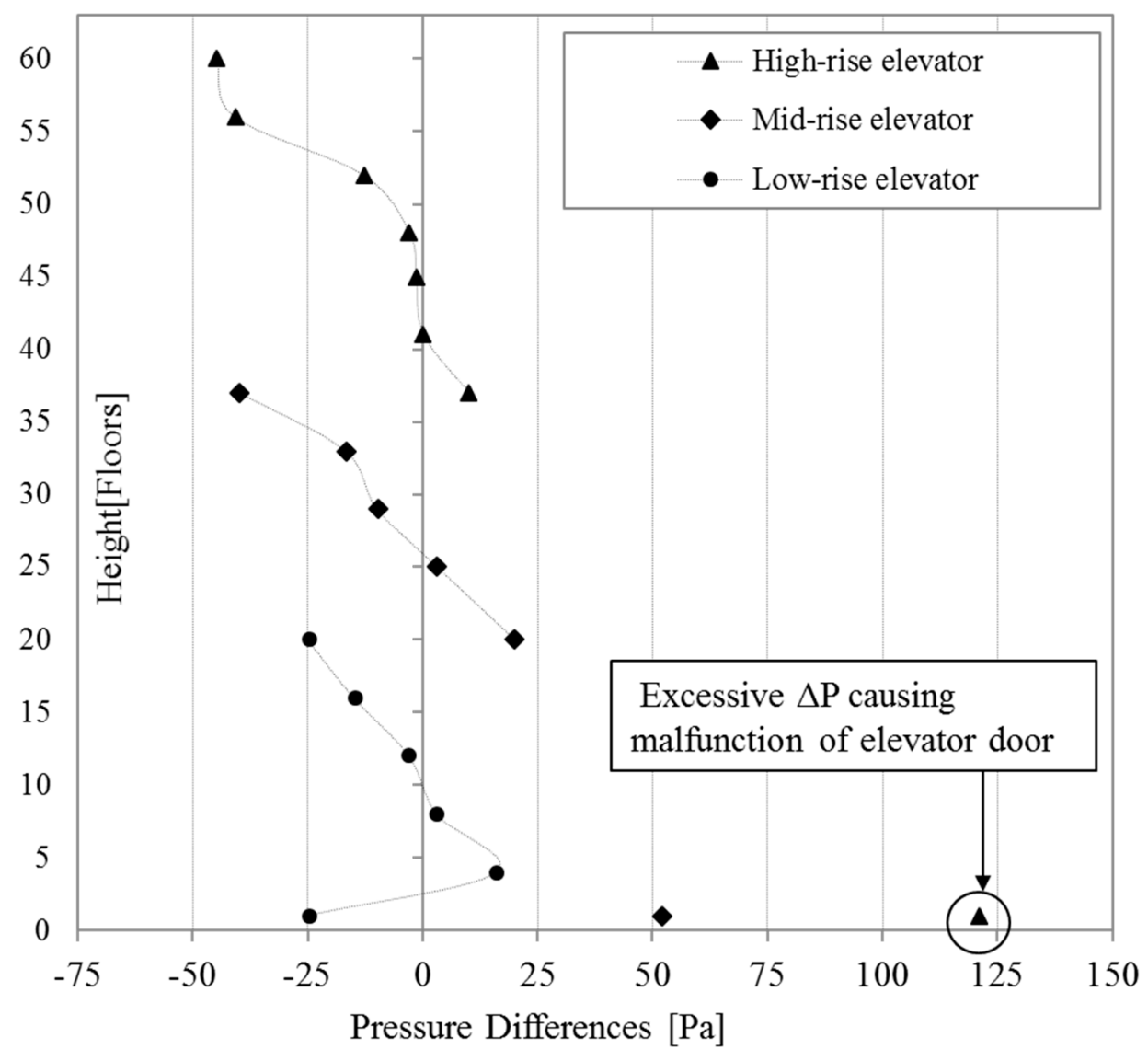

Figure 4. Pressure differences across the elevator doors (outdoor air temperature: $-5.2{ }^{\circ} \mathrm{C}$, indoor air temperature: $22{ }^{\circ} \mathrm{C}$ ).

\subsection{Computer Simulations of HVAC Operations}

An initial computer simulation was conducted to validate the accuracy of the computer model by comparing the calculated results with the results obtained from the initial measurements mentioned above for the existing conditions without pressurization when the outdoor and indoor air temperatures were $-5.2{ }^{\circ} \mathrm{C}$ and $22{ }^{\circ} \mathrm{C}$, respectively.

\subsubsection{Validation of Computer Model}

The computer program used in this study was CONTAM [25], developed by the National Institute of Standards and Technology (NIST) in the United States. Figure 5 shows CONTAM models for the first floor and a typical floor (50th floor) serviced by the high-rise elevator shaft. The computer model includes major elevator shafts, stairwell shafts, ceiling-mounted air diffusers, doors for the office zones and the building envelope.

Table 1 shows the air leakage data for the computer simulation which were measured values or values recommended by Tamura [4] and ASHRAE [26]. Figure 6 shows the measured and calculated $\Delta \mathrm{Ps}$. As shown in the figure, the $\Delta \mathrm{P}$ profiles of the two values showed a close pattern and the relative error between the greatest measured and calculated $\Delta$ Ps was $7 \%$. 


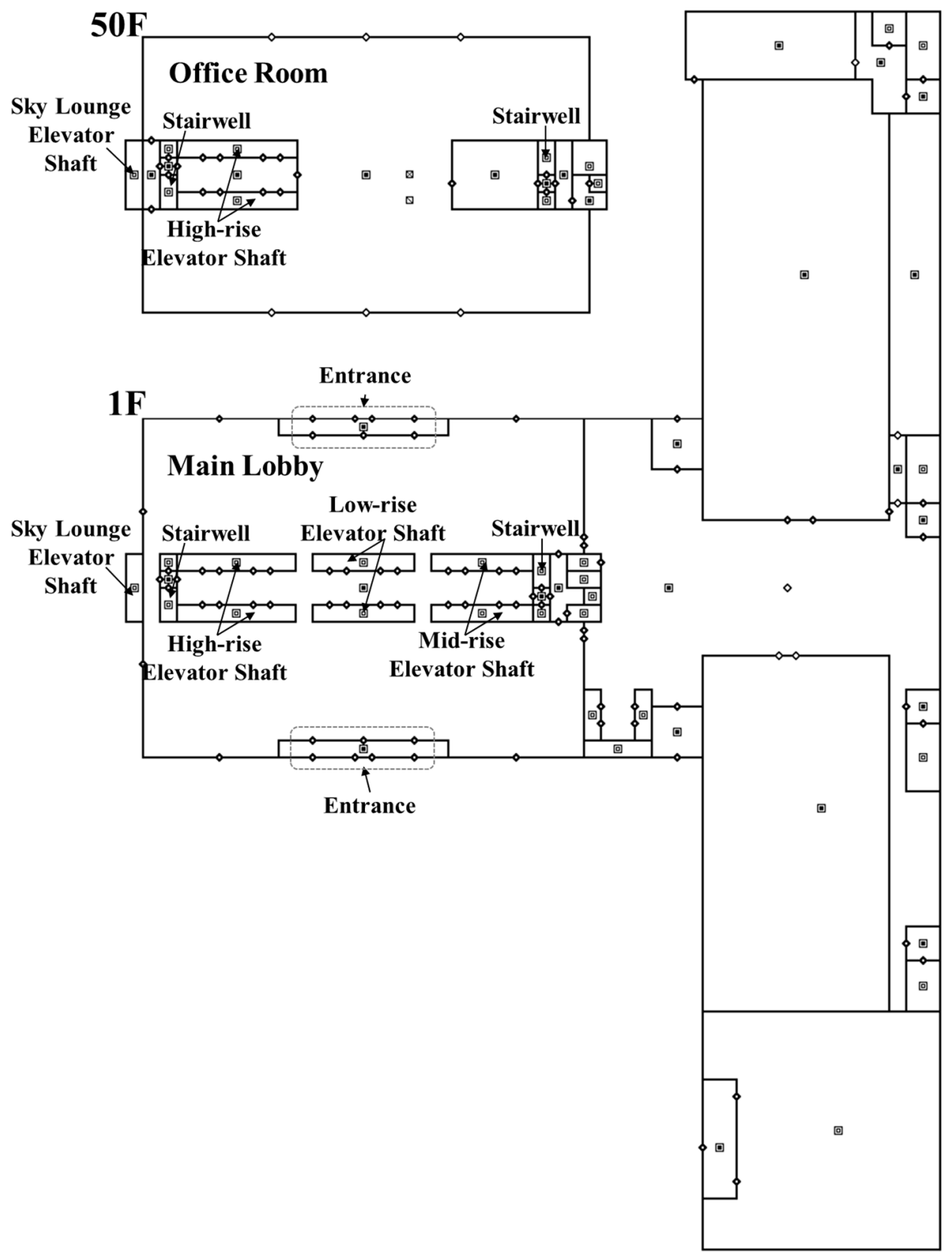

Figure 5. The CONTAM model for the 1st floor and a typical floor (50th floor) serviced by a high-rise elevator shaft. 
Table 1. Air leakage data used for initial computer simulations.

\begin{tabular}{ccc}
\hline Location & Air Leakage Data & Source \\
\hline Elevator door & EqLA $_{75}{ }^{1} 240 \mathrm{~cm}^{2} /$ item(closed) & Tamura [4] \\
Stairwell door & EqLA $_{75} 130 \mathrm{~cm}^{2} /$ item(closed) & Tamura [4] \\
Revolving door & EqLA $_{4} 21020 \mathrm{~cm}^{2} /$ item & Measured data \\
Swing door & EqLA $_{4} 53 \mathrm{~cm}^{2} /$ item(closed) & ASHRAE [26] \\
Sliding door & EqLA $_{4} 100 \mathrm{~cm}^{2} /$ item(closed) & ASHRAE [26] \\
Door for office room & EqLA $_{4} 2.1 \mathrm{~m}^{2} /$ item $($ open) & Measured data \\
Exterior wall of lobby & EqLA $_{75} 4.88 \mathrm{~cm}^{2} / \mathrm{m}^{2}\left(\mathrm{~A}_{\mathrm{L}} / \mathrm{A}_{\text {wall }}\right)$ & Tamura [4] \\
Exterior wall of typical floors & EqLA $_{75} 3.60 \mathrm{~cm}^{2} / \mathrm{m}^{2}\left(\mathrm{~A}_{\mathrm{L}} / \mathrm{A}_{\text {wall }}\right)$ & Tamura [4] \\
\hline
\end{tabular}

${ }^{1}$ EqLA $_{75}$ : Equivalent leakage area at $75 \mathrm{~Pa}^{2} \mathrm{EqLA}_{4}$ : Equivalent leakage area at $4 \mathrm{~Pa}$.

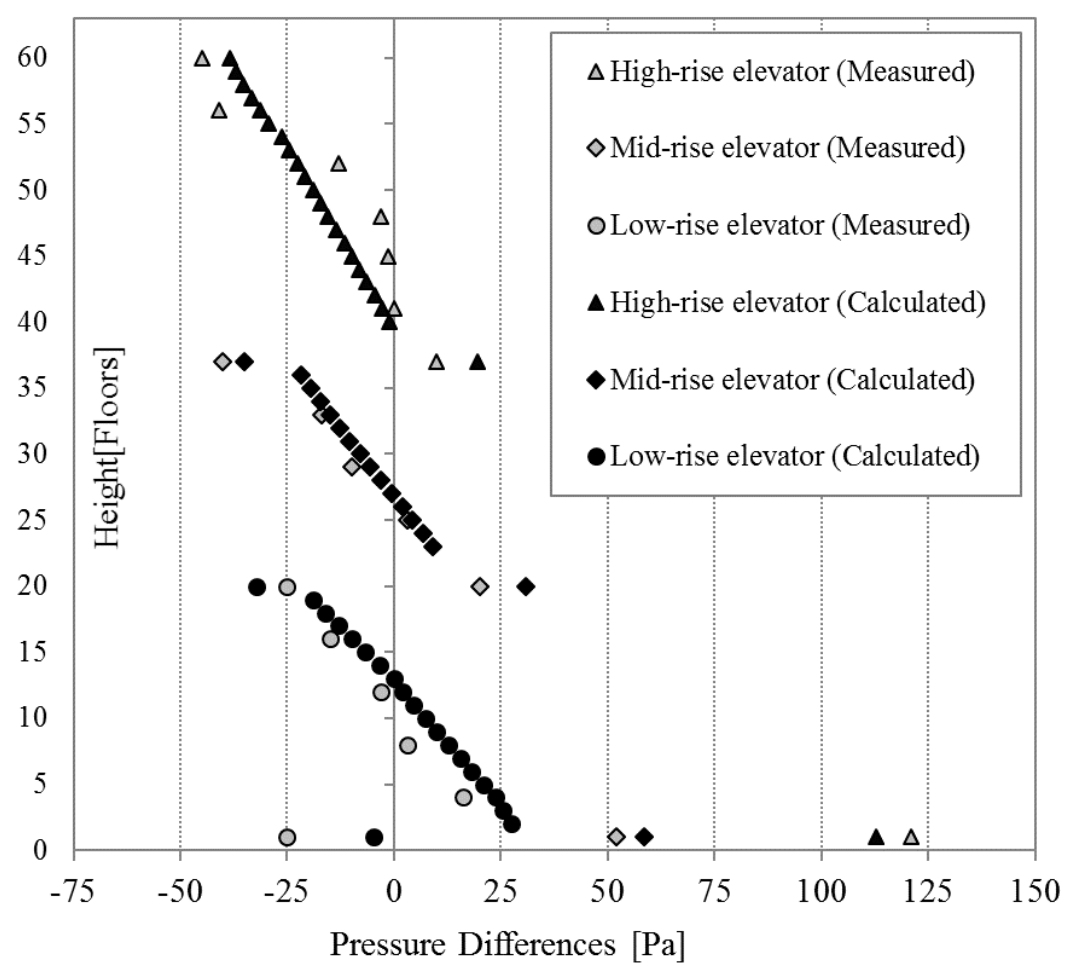

Figure 6. Measured and calculated $\Delta \mathrm{Ps}$ without pressurization (outdoor air temperature: $-5.2{ }^{\circ} \mathrm{C}$, indoor air temperature: $22^{\circ} \mathrm{C}$ ).

\subsubsection{Computer Simulation}

As mentioned above, this study suggested pressurization of the upper part of the building by the HVAC systems to reduce the great $\triangle$ Ps across the elevator doors that were confirmed by field measurements. In this study, the group of floors on the upper part of the building to be pressurized was determined through computer simulations. In addition, the required air volume for pressurization $\left(\mathrm{V}_{\mathrm{PA}}\right)$ was also determined.

The design outdoor and indoor air temperatures for heating in the computer simulations were $-11.3^{\circ} \mathrm{C}$ and $20^{\circ} \mathrm{C}$ [27], respectively. The outdoor wind velocity was set to $0 \mathrm{~m} / \mathrm{s}$ to eliminate the effects of external wind. Table 2 shows the pressurization conditions for different groups of floors. The base case refers to the existing condition without pressurization. Cases 1-3 involve various pressurization conditions. Case 1 was where the whole building was pressurized. Case 2 was where Floors 23-60 were pressurized, where the mid-rise and high-rise elevators were operated. In Case 2, Floors 38 and 39 were excluded because they are mechanical floors. Case 3 was where Floors 40-60 
were pressurized, where only the high-rise elevators were operated. For each case, HVAC operations were simulated with three different $\mathrm{V}_{\mathrm{PA}}$ volumes; these are denoted as $\mathrm{A}, \mathrm{B}$, and $\mathrm{C}$ in the case names. For Cases 1-3, the respective volumes of $V_{P A}$ of 3000, 6000 and $9000 \mathrm{~m}^{3} / \mathrm{h}$ were used for each floor.

Table 2. Pressurization conditions used in the computer simulations.

\begin{tabular}{cccc}
\hline Cases & Floors for Pressurization & $\mathbf{V}_{\mathbf{P A}}$ Per Floor $\left[\mathbf{m}^{3} / \mathbf{h}\right]$ & Total $\mathbf{V}_{\mathbf{P A}}\left[\mathbf{m}^{\mathbf{3}} / \mathbf{h}\right]$ \\
\hline Base case & None & None & None \\
\hline Case 1A & \multirow{3}{*}{$1-60$} & 3000 & 180,000 \\
Case 1B & & 6000 & 360,000 \\
Case 1C & & 9000 & 540,000 \\
\hline Case 2A & \multirow{2}{*}{$23-37$ and 40-60 } & 3000 & 108,000 \\
Case 2B & & 6000 & 216,000 \\
Case 2C & & 9000 & 324,000 \\
\hline Case 3A & \multirow{2}{*}{$40-60$} & 3000 & 63,000 \\
Case 3B & & 6000 & 126,000 \\
Case 3C & & 9000 & 189,000 \\
\hline
\end{tabular}

\subsubsection{Simulation Results}

Figures 7-9 show the simulation results of $\Delta \mathrm{P}$ across the elevator doors obtained from Cases 1, 2, and 3 compared to the base case. As shown in the figures, most of the $\Delta$ Ps across the elevator doors except for the high-rise elevator doors on the first floor were smaller than $100 \mathrm{~Pa}$. Therefore, only the $\Delta$ Ps across the high-rise elevator doors on the first floor were summarized in Table 3 with the required air volume for each case. As shown in the table, $\Delta \mathrm{P}$ for the base case was $141.5 \mathrm{~Pa}$, exceeding the threshold of $100 \mathrm{~Pa}$.

When the whole building was pressurized, $\Delta \mathrm{P}$ was smaller than $100 \mathrm{~Pa}(96.9 \mathrm{~Pa})$ for Case $1 \mathrm{~B}$ and the required total air volume was calculated as $360,000 \mathrm{~m}^{3} / \mathrm{h}$. When the mid zone (Floors 23-37) and upper zone (Floors $40-60$ ) were pressurized, $\triangle \mathrm{P}$ was $87.6 \mathrm{~Pa}$ for Case $2 \mathrm{~B}$ and the required total air volume was $216,000 \mathrm{~m}^{3} / \mathrm{h}$. Finally, $\Delta \mathrm{P}$ and the total air volume were further reduced to $89.3 \mathrm{~Pa}$ and $126,000 \mathrm{~m}^{3} / \mathrm{h}$, respectively for Case $3 \mathrm{~B}$, in which only the upper zone was pressurized. From this comparative computer simulation process, Case $3 \mathrm{~B}$ was selected as a candidate pressurization scheme, because this scheme required a comparatively smaller volume of air than the other schemes did. However, Case 3B could not be considered an optimum scheme because $\Delta \mathrm{P}(89.3 \mathrm{~Pa})$ was noticeably smaller than $100 \mathrm{~Pa}$, suggesting the possibility of further reducing the total air volume.

Therefore, further computer simulations were performed to find an optimum scheme by reducing the air volume for pressurization until $\Delta \mathrm{P}$ became smaller than but closer to $100 \mathrm{~Pa}$. Finally, it was found that when the total air volume was reduced to $105,000 \mathrm{~m}^{3} / \mathrm{h}$, the $\Delta \mathrm{P}$ was increased to $99.8 \mathrm{~Pa}$. Figure 10 shows the floor-by-floor distributions of $\Delta \mathrm{P}$ across the elevator doors due to this final pressurization scheme. 


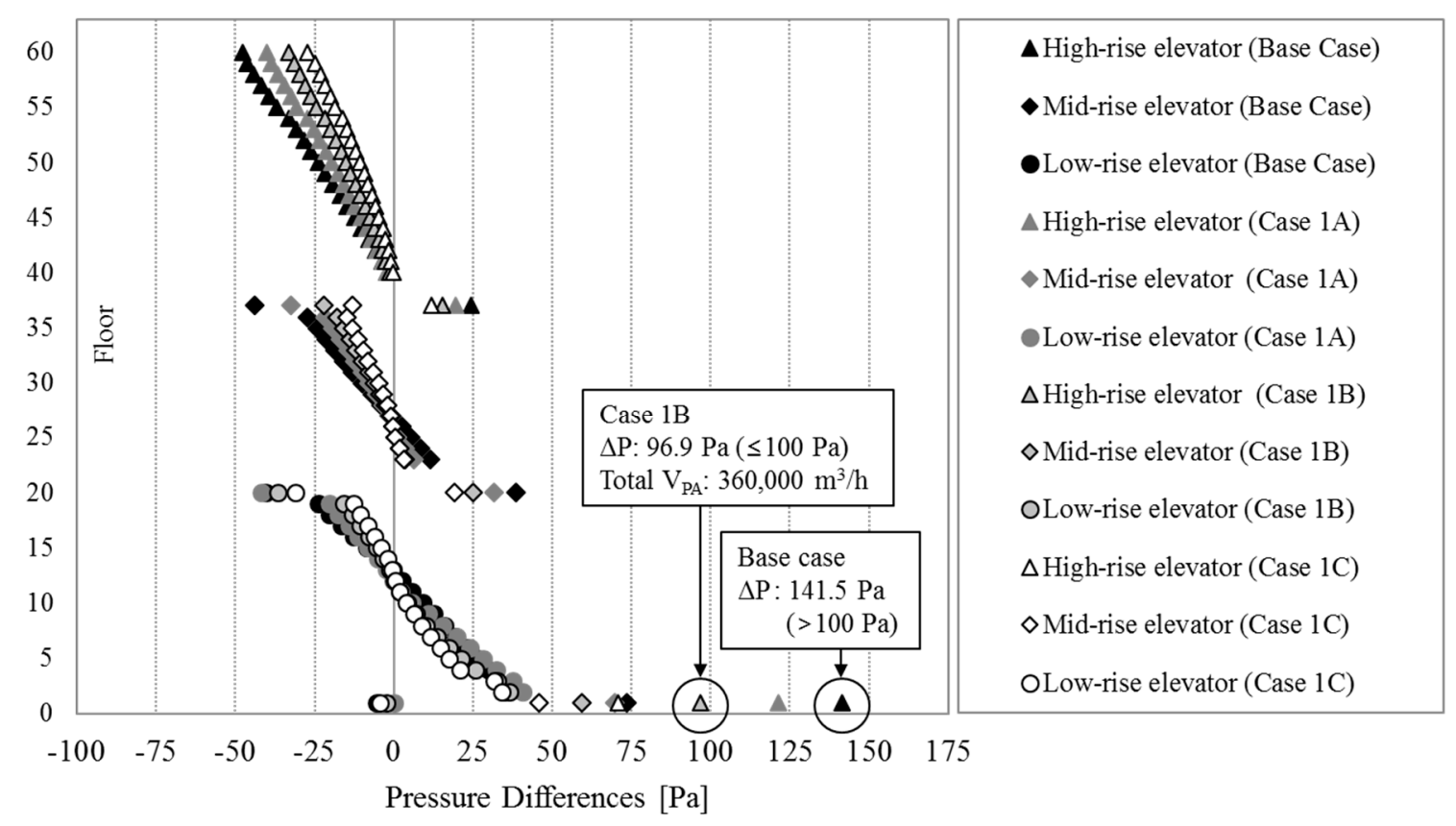

Figure 7. Comparison of pressure differences across the elevator doors: Case 1 vs. the base case.

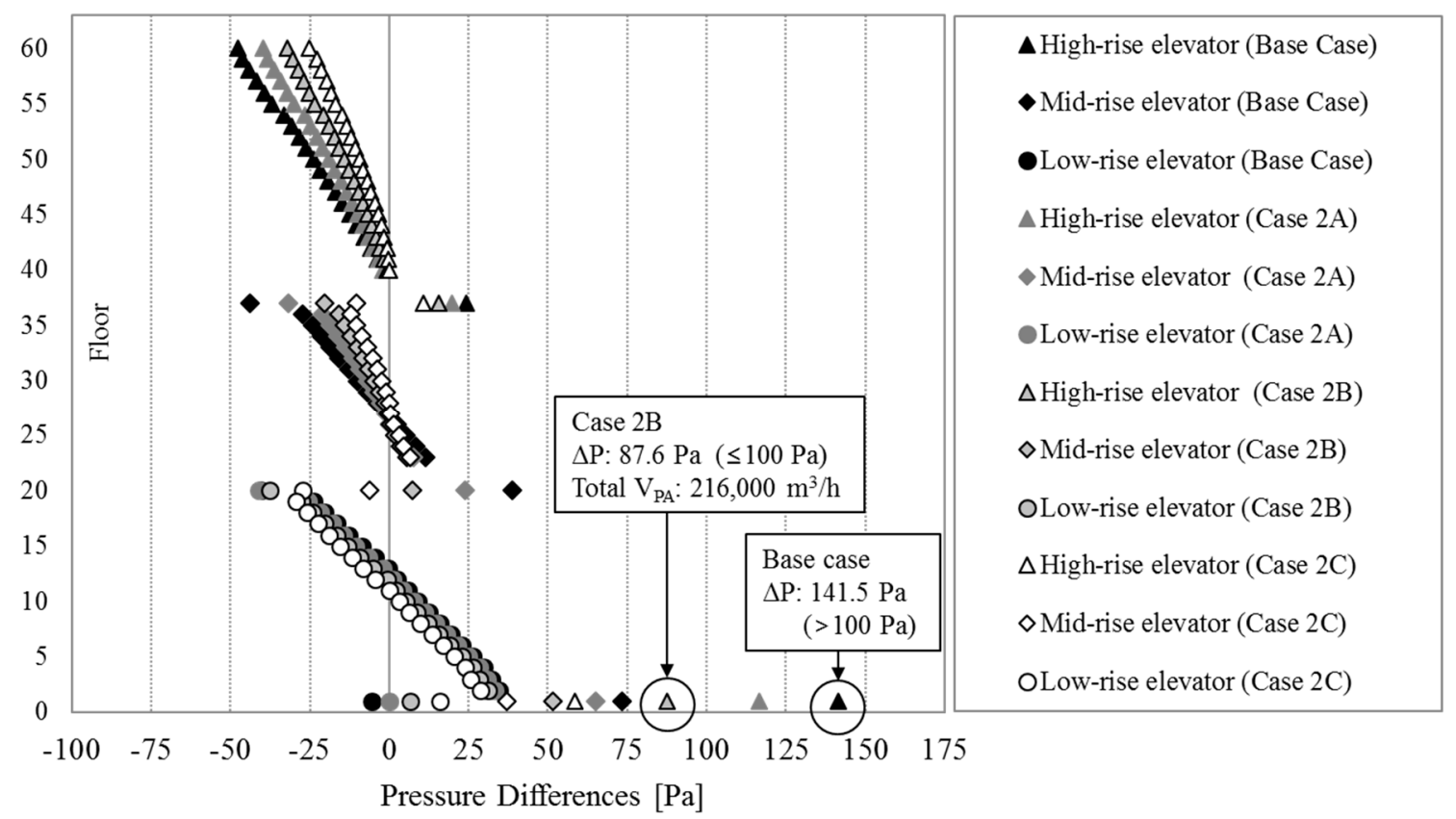

Figure 8. Comparison of pressure differences across the elevator doors: Case 2 vs. the base case. 


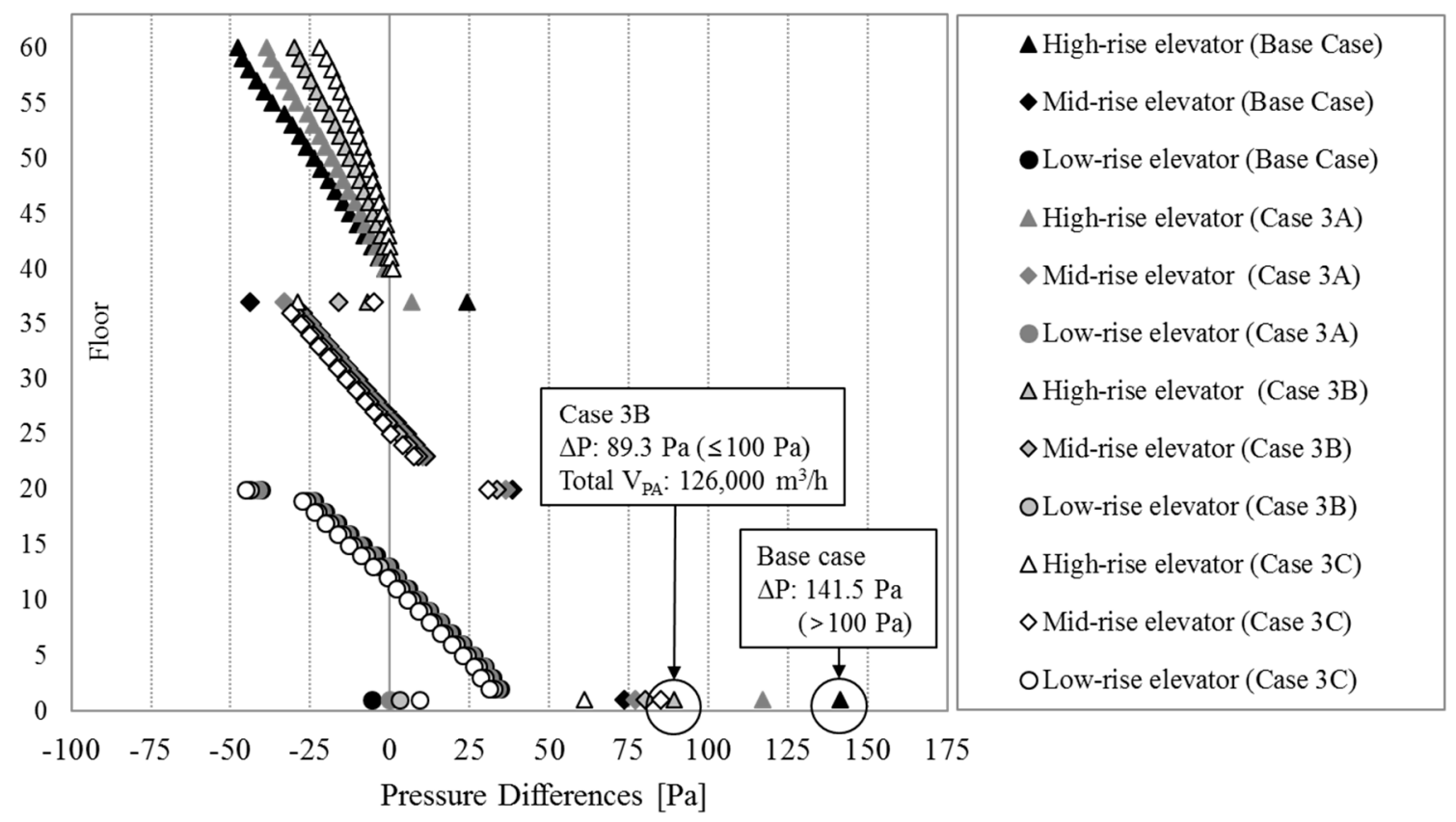

Figure 9. Comparison of pressure differences across the elevator doors: Case 3 vs. the base case.

Table 3. Pressure differences across high-rise elevator doors on the first floor and total air volumes for pressurizations.

\begin{tabular}{ccc}
\hline Cases & $\boldsymbol{\Delta \mathbf { P } [ \mathbf { P a } ]}$ & Total $\mathbf{V}_{\mathbf{P A}}\left[\mathbf{m}^{3} / \mathbf{h}\right]$ \\
\hline Base case & 141.5 & None \\
Case 1A & 121.4 & 180,000 \\
Case 1B & 96.9 & 360,000 \\
Case 1C & 70.7 & 540,000 \\
Case 2A & 116.4 & 108,000 \\
Case 2B & 87.6 & 216,000 \\
Case 2C & 58.3 & 324,000 \\
Case 3A & 117.1 & 63,000 \\
Case 3B & 89.3 & 126,000 \\
Case 3C & 61 & 189,000 \\
\hline
\end{tabular}




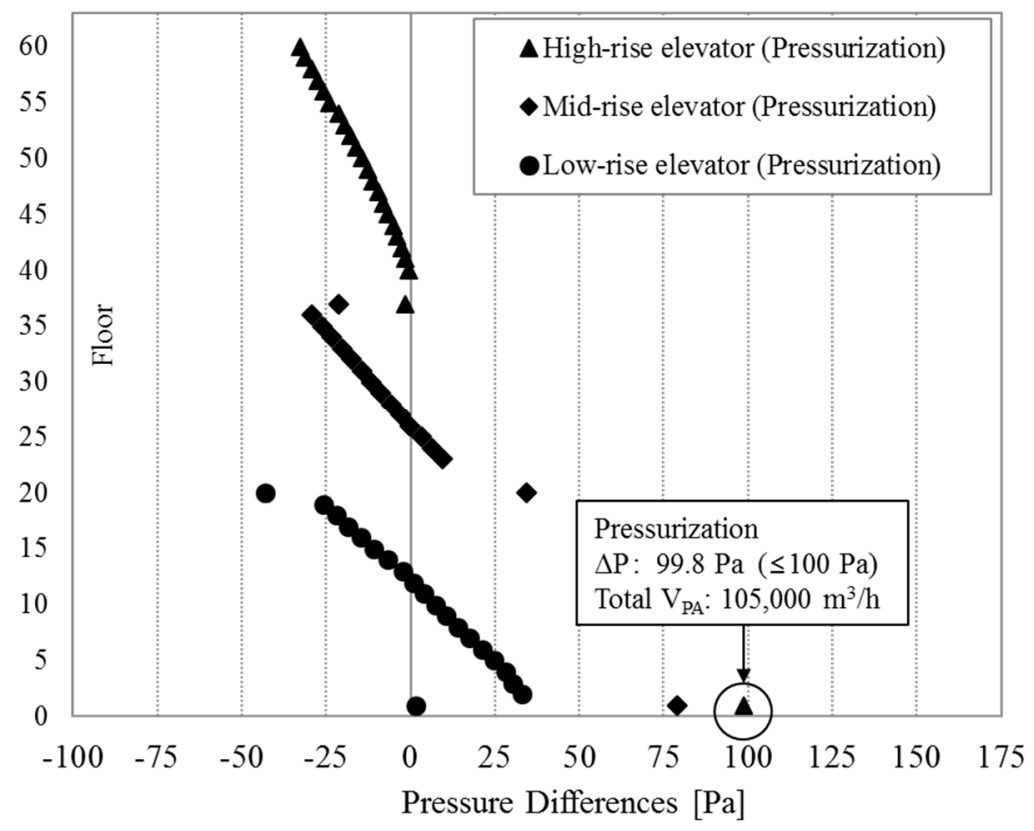

Figure 10. Pressure differences across elevator doors due to the optimum pressurization scheme.

\subsection{Field Application and Adjustment}

\subsubsection{Implementing the Simulation Result in an Actual Building}

The optimum pressurization scheme identified by the computer simulation was implemented in an actual building by controlling the HVAC system, shown schematically in Figure 11. The diagram represents the groups of fans and dampers for the pressurized zone (Floors 40-60). It shows fans for the supply air (SA) and return air (RA) and various dampers for OA, recirculated air (CA) and EA. It also shows the dedicated exhaust fans for the rest rooms.

At first, a simple operation was tried by admitting outdoor air but not allowing exhaust air from the HVAC system and the restrooms in order to increase the air pressure in the office rooms. As depicted in Figure 11, only the SA fans were operated at a constant speed and the OA and CA dampers were operated to bring in outdoor air and circulate the air through the HVAC system, while the EA dampers were closed. At the same time, the RA fans and EA fans for the rest rooms were not operated. Then, measurements were conducted to examine if the evaluation criterion of $100 \mathrm{~Pa}$ or smaller for $\Delta \mathrm{P}$ across high-rise elevator doors on the first floor was achieved. The measurements were conducted from 10:00 p.m. to 12:00 a.m. on 2 February 2012 when the outdoor air temperatures were between -10.6 and $-11.2^{\circ} \mathrm{C}$, which were typical design outdoor temperatures in heating seasons for the Seoul area. The indoor temperature was maintained at $20^{\circ} \mathrm{C}$.

From this simple HVAC system operation, a $\mathrm{V}_{\mathrm{PA}}$ close to the simulation result was obtained as shown in Table 4. By controlling the HVAC system with the various combinations of damper operations, a $\mathrm{V}_{\mathrm{PA}}$ of $109,000 \mathrm{~m}^{3} / \mathrm{h}$ was obtained by opening the $\mathrm{OA}$ dampers by $40 \%$ and $\mathrm{CA}$ dampers by $60 \%$, while the EA dampers were closed. The measured $\triangle \mathrm{P}$ across the high-rise elevator doors on the first floor was $95 \mathrm{~Pa}$ by this operation, while it was $135 \mathrm{~Pa}$ and the elevator doors could not be closed when the target zone (Floors 40-60) was not pressurized. Figure 12 shows the floor-by-floor $\Delta$ Ps before and after pressurization. 


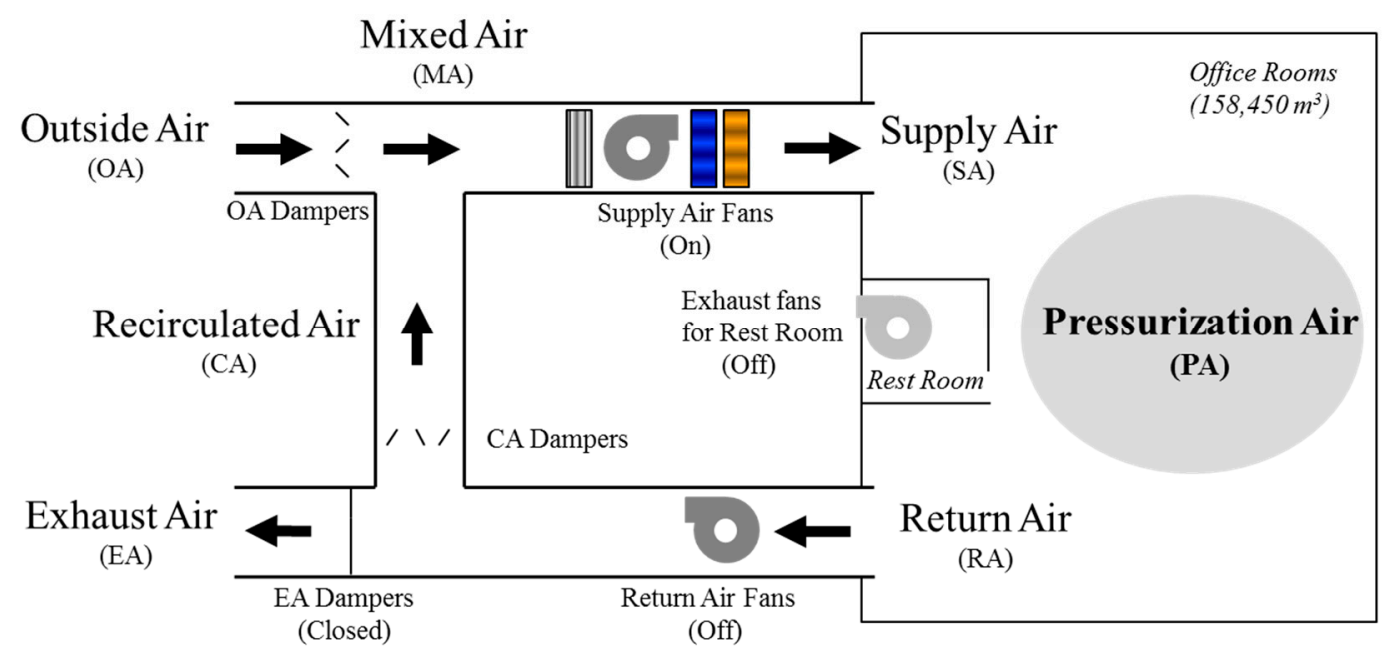

Figure 11. HVAC operation scheme for the pressurized zone (Floors 40-60).

Table 4. Damper controls for pressurization.

\begin{tabular}{|c|c|c|c|c|c|}
\hline Controls & OA Damper (\%) & CA Damper (\%) & EA Damper (\%) & $\mathrm{V}_{\mathrm{PA}}\left(\mathrm{m}^{3} / \mathrm{h}\right)$ & $\Delta \mathrm{P}^{1}(\mathrm{~Pa})$ \\
\hline \multirow{5}{*}{$\begin{array}{c}\text { Actual HVAC } \\
\text { System Operations }\end{array}$} & 0 & 100 & 0 & 0 & 135 \\
\hline & 10 & 90 & 0 & 27,333 & 110 \\
\hline & 20 & 80 & 0 & 54,667 & 107 \\
\hline & 30 & 70 & 0 & 82,000 & 105 \\
\hline & 40 & 60 & 0 & 109,333 & 95 \\
\hline Computer Simulation & - & - & - & 105,000 & 99.8 \\
\hline
\end{tabular}

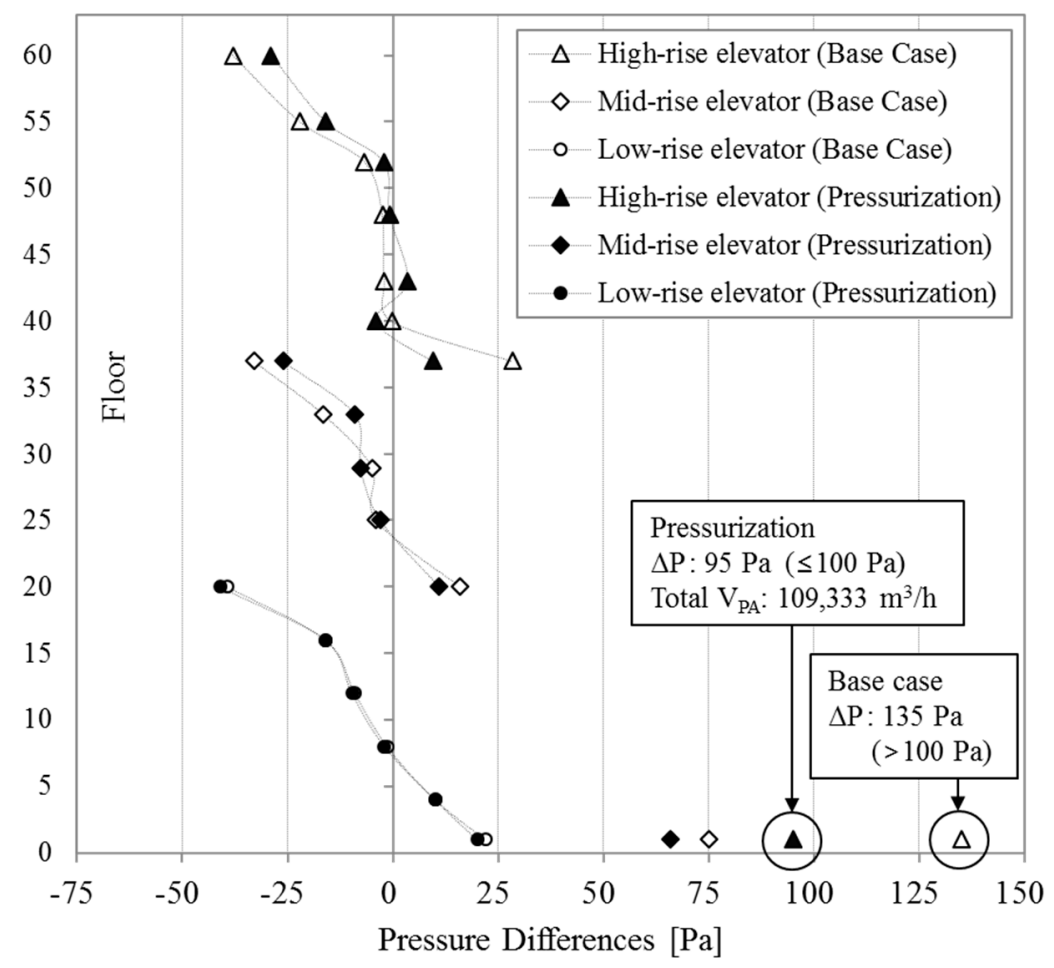

Figure 12. Pressure differences across elevator doors: before and after pressurization. 


\subsubsection{Actual HVAC Operation}

After deciding the total $\mathrm{V}_{\mathrm{PA}}$ needed to solve the stack effect problem without considering the ventilation requirement as described above, actual volumes of OA and EA were adjusted according to the required ventilation. When the test building was ventilated as recommended by ASHRAE [28], in which $29 \mathrm{~m}^{3} / \mathrm{h}$ /person of fresh OA is required for about 200 people/floor in the pressurized zone consisting of 21 floors (Floors 40-60), the actual required OA was about 121,800 $\mathrm{m}^{3} / \mathrm{h}$. Since the $\mathrm{V}_{\mathrm{PA}}$ for pressurization was $109,333 \mathrm{~m}^{3} / \mathrm{h}$, the dampers for EA and exhaust fans for the restrooms, shown in Figure 12, were operated by the building operators such that the sum of EA from the HVAC system and the restrooms was maintained at about $12,467 \mathrm{~m}^{3} / \mathrm{h}$.

\section{Conclusions}

This study was conducted to find an effective HVAC operation scheme to solve the stack effect problem in a 60-story commercial building located in Seoul, Korea. A series of field measurements were conducted in the winter to identify problems related to the stack effect. Then, a series of computer simulations were conducted to find an effective HVAC operation scheme to reduce the stack effect. The results from the computer simulations were implemented in the field and adjusted to find an optimum HVAC system operation scheme. The whole process and results can be summarized as follows:

(1) From the initial field measurements, the evaluation criterion was established for the pressure difference $(\Delta \mathrm{P})$ across the high-rise elevator doors on the first floor to be below $100 \mathrm{~Pa}$ to ensure smooth opening and closing of these elevator doors.

(2) The CONTAM computer program was used to find effective HVAC operation schemes. From this procedure, the decided upon scheme was to pressurize the upper zone of the building, from the 40th to 60th floor. Then, further computer simulations were conducted to find a scheme to minimize the total air volume for pressurization $\left(\mathrm{V}_{\mathrm{PA}}\right)$. The scheme selected as the most effective and efficient HVAC operation for this particular building was to pressurize the upper building zone (Floors 40-60) with $105,000 \mathrm{~m}^{3} / \mathrm{h}$ of $\mathrm{V}_{\mathrm{PA}}$.

(3) This optimized pressurization scheme identified by the computer simulation was implemented in the actual building by controlling the dampers and fans in the HVAC system. At first, a simple operation was attempted to bring in outdoor air (OA) while not allowing exhaust air (EA) in order to increase the air pressure in the office rooms. From this procedure, it was found that when the upper zone of the building (Floors 40-60) was pressurized with 109,333 $\mathrm{m}^{3} / \mathrm{h}$ of $\mathrm{V}_{\mathrm{PA}}$ under the winter design outdoor temperature condition in heating seasons in the Seoul area, the $\Delta \mathrm{P}$ across the first-floor elevator door for the high-rise elevator shaft was reduced from $135 \mathrm{~Pa}$ to $95 \mathrm{~Pa}$ and the elevator door started closing smoothly.

(4) Finally, the actual OA was adjusted to $121,800 \mathrm{~m}^{3} / \mathrm{h}$ by considering ventilation requirements and about $12,467 \mathrm{~m}^{3} / \mathrm{h}$ of air was exhausted from the zone.

Even though the specific number of floors to be pressurized and the specific air volume for pressurization were applicable to this specific building, the four steps summarized above can be applied to other high-rise buildings to identify and solve the stack effect related problems.

This study was conducted under the design outdoor air temperature condition in the Seoul area with negligible effects of external wind. Therefore, further work should be conducted to find more flexible, generalizable, and effective HVAC operation schemes for different boundary layer conditions such as outdoor air temperature, wind speed, and humidity, as discussed in the previous study [29].

Author Contributions: All authors contributed substantially to all aspects of this article.

Conflicts of Interest: The authors declare no conflict of interest. 


\section{References}

1. Chen, Y.; Tong, Z.; Malkawi, A. Investigating natural ventilation potentials across the globe: Regional and climatic variations. Build. Environ. 2017, 122, 386-396. [CrossRef]

2. Oropeza-Perez, I.; Østergaard, P.A. Energy saving potential of utilizing natural ventilation under warm conditions-A case study of Mexico. Appl. Energy 2014, 130, 20-32. [CrossRef]

3. Lovatt, J.E.; Wilson, A.G. Stack Effect in Tall Buildings; American Society of Heating, Refrigerating and Air-Conditioning Engineers, Inc.: Atlanta, GA, USA, 1994; pp. 420-431.

4. Tamura, G.T. Smoke Movement and Control in High-Rise Buildings; National Fire Protection Association: Quincy, MA, USA, 1994.

5. Klote, J.H.; Evans, D.H. A Guide to Smoke Control in the 2006 IBC; International Code Council: Washington, DC, USA, 2007.

6. Hayakaya, S.; Togari, S. Study on the stack effect of tall office building (Part1). J. Archit. Inst. Jpn. 1988, 387, $42-52$.

7. Jo, J.H.; Lim, J.H.; Song, S.Y.; Yeo, M.S.; Kim, K.W. Characteristics of pressure distribution and solution to the problems caused by stack effect in high-rise residential buildings. Build. Environ. 2007, 42, 263-277. [CrossRef]

8. Lstiburek, J.W. Understanding air barriers. ASHRAE J. 2005, 47, 24-30.

9. Yu, J.Y.; Cho, D.W.; Song, K.D. Case Studies of the Design Alternatives to Minimize Stack Effect Problems in Tall Buildings. In Proceedings of the BUEE 2006, Tokyo, Japan, 10-13 July 2006; pp. 415-420.

10. Yu, J.Y.; Cho, D.W.; Song, K.D. The Design Procedure for Reducing Stack Effect Problems in Tall Complex Building. In Proceedings of the 11th International Conference on Indoor Air Quality and Climate, Copenhagen, Denmark, 17-22 August 2008; p. 773.

11. Tamura, G.T.; Wilson, A.G. Building pressures caused by chimney action and mechanical ventilation. ASHRAE Trans. 1967, 73, 2.2.1-2.2.12.

12. Tamblyn, R.T. Coping with air pressure problems in tall buildings. ASHRAE Trans. 1991, 97, 824-827.

13. ASHRAE. Field Verification of Problems Caused by Stack Effect in Tall Buildings; ASHRAE Research Project Report RP-661; American Society of Heating, Refrigerating, and Air-Conditioning Engineers: Atlanta, GA, USA, 1993.

14. Ross, D.E. HVAC Design Guide for Tall Commercial Buildings; ASHRAE: Atlanta, GA, USA, 2004.

15. Tamblyn, R.T. HVAC system effects for tall buildings. ASHRAE Trans. 1993, 99, 789-792.

16. Klote, J.H. The ASHRAE Design manual for smoke control. Fire Saf. J. 1984, 7, 93-98. [CrossRef]

17. ASHRAE. ASHRAE Handbook 2009 Fundamentals; ASHRAE: Atlanta, GA, USA, 2009.

18. Schmidt, W. Stairwell and elevator shaft pressurization. Fire Saf. J. 1984, 7, 115-116. [CrossRef]

19. Miller, R.S.; Beasley, D. On stairwell and elevator shaft pressurization for smoke control in tall buildings. Build. Environ. 2009, 44, 1306-1317. [CrossRef]

20. Lee, J.H.; Song, D.S.; Park, D.R. A study on the development and application of the E/V shaft cooling system to reduce stack effect in high-rise buildings. Build. Environ. 2010, 45, 311-319. [CrossRef]

21. Klote, J.H.; Milke, J.A. Principle of Smoke Management; ASHRAE: Atlanta, GA, USA, 2002.

22. Klote, J.H. NISTIR 4588: A General Routine for Analysis of Stack Effect; NIST, U.S. Department of Commerce: Gaithersburg, MD, USA, 1991.

23. NRC-CNRC. National Building Code of Canada; NRC-CNRC: Ottawa, ON, Canada, 2005.

24. Lstiburek, J.W. Multifamily Buildings: Controlling Stack Effect-Driven Airflows. ASHRAE J. 2005, 47, 30-39.

25. Dols, W.S.; Walton, G.N. NISTIR 7251-CONTAM User Guide and Program Documentation; National Institute of Standards and Technology: Gaithersburg, MD, USA, 2013.

26. ASHRAE. ASHRAE Handbook 1997 Fundamentals; ASHRAE: Atlanta, GA, USA, 1997.

27. Ministry of Land, Infrastructure and Transport. Energy Saving Design Standard of Building; Ministry of Land, Infrastructure and Transport: Sejong-si, Korea, 2017. 
28. ASHRAE. STD 62.1 Ventilation for Acceptable Indoor Air Quality; ASHRAE: Atlanta, GA, USA, 2004.

29. Tong, Z.; Chen, Y.; Malkawi, A. Estimating natural ventilation potential for high-rise buildings considering boundary layer meteorology. Appl. Energy 2017, 193, 276-286. [CrossRef] 